\title{
A review of Policies on Geometric Design of Freeways: Portugal and United States of America
}

\author{
Lígia Conceição ${ }^{1}$, Carlos Rodrigues ${ }^{1,2}$ \\ ${ }^{1}$ Department of Civil Engineering, Faculty of Engineering, University of Porto, R. Dr. Roberto \\ Frias, 4200-465 Porto, Portugal (ligia.conceicao@fe.up.pt); ${ }^{2}$ CITTA - Research Centre for \\ Territory, Transports and Environment, Porto, Portugal (cmr@fe.up.pt)
}

\begin{abstract}
Once freeways are classified as arterial systems, they are directly associated to accessibility which has implications on efficiency of a road network design. The geometric design standards influence the freeways' conception and operation and, therefore, they certainly have an impact on accessibility and the country's development.

A comparative analysis of geometric design of freeways was focused on two policies, both from Portugal and United States of America. The data gathered the geometric parameters regarding the design controls, criteria, elements of design and cross section elements.

The major finding of this review infers that the Portuguese Policy imply wider and extensive freeways that arise from strong restraints in the minimum values of geometric parameters. This reflects on higher safety frame. The American Policy is less conservative which may reflect on slender geometric freeways, in comparison with the Portuguese. Therefore, it may be assumed that the American Policy designs less expensive freeways.

Subject Headings. Transport Policy, Expressway, Deregulation, Public Works, Road Building, Construction Policy

Author Keywords. Highway Engineering, Geometric Design, Standard, Policy, Expressway, Freeway, Portugal, USA
\end{abstract}

\section{Introduction}

In any highway project, the design is a complex problem, sometimes biased and undetermined, being the foremost characteristics that prevail through project conception. Therefore, the highway engineer is confronted with numerous aspects that justify caution, such limitations arise from: the preliminary program provided by the client, the technicalgeometric characteristics, topography, hydrology, geotechnics, urban form and land-use, environmental impacts, budgets, social factors, among others.

The preliminary program defines the general characteristics of the project, the fixed points and the basic elements that outline the geometric characteristics. The basic elements gather the design speed and the traffic level desired. The design speed compromises the geometric features in horizontal and vertical alignment, whereas the traffic level has major impact in the cross section elements.

The geometric characteristics are regulated by the standards of each country. Then the minimum values of each geometric parameter are the main constraint that the designer is subjected to. Nonetheless, the geometric characteristics must be integrated with the others constraints which is the challenge. 
A road network involves arterial systems, collector systems and local road systems that balance between mobility and accessibility. A freeway is normally classified as a principal arterial system, though it is not a functional class itself. It is usually associated with mobility once it is estimated to guarantee movement between urban areas with populations of over 25,000 and also 50,000 with respect to the level of service assumed (AASHTO 2011). A short definition for a freeway is an arterial system within which motor vehicles can circulate at high speeds in two directions of traffic within a separated corridor and with no level intersections (InIR 2008).

Therefore, each country has its own policy that regulates the highway design which intends to give flexibility within the geometric design. This paper analyses the policies on geometric design of freeways undertaken in Portugal and United States of America.

The comparative analysis on freeway geometric design relies in the standards analysis to verify the dissimilarities in each element design. Both standards are critically analysed among the design theories and the minimum admissible values that result from preceding requirements.

In Portugal, the current document that regulates the highway design is the InIR (2010) which is an adaption from the previous Portuguese standard, JAE (1994). In USA, the policy on geometric design is disseminated by AASHTO (2011). The Portuguese freeway features are available in InIR (2008) document and, in USA, these characteristics are comprehended in AASHTO (2005).

According to the last Portuguese standard revision, there exist four categories of freeways (InIR 2008):

- Interurban freeway: for traffic of medium and long distances (access nodes spaced 8 km apart)

- Interurban freeway in difficult topography: similar to the last definition but in rough terrain and with lengths over $10 \mathrm{~km}$ (access nodes spaced $8 \mathrm{~km}$ apart)

- Suburban freeway: part of the National Roadway Plan, PRN (2000), located in the urban periphery and serving interurban traffic (traffic pendular) around a metropolitan area (access nodes: $2 \mathrm{~km}$ )

- Urban freeway: part of the National Roadway Plan, PRN (2000), situated in urban zones and diffusing metropolitan traffic into interurban zones (access nodes: 1.5 $\mathrm{km})$.

In the United States of America, the arterial systems that are similar to the "freeway" concept are divided in three main groups (FHT 2013):

- Interstates: the major level of mobility, they are delineated in separate carriageways for the two directions of traffic;

- freeways and expressways: with two distinct directions of high-speed traffic that are separated by physical barriers;

- urban and rural arterials: surround the metropolitan/rural centres with high mobility and serve the commuting movements.

It is important to denote that the distance between the access nodes in American freeways is $1.5 \mathrm{~km}$ for urban areas and $5 \mathrm{~km}$ for rural areas. Besides, it is also possible that in urban areas the access nodes may be under $1.5 \mathrm{~km}$ which connect to traffic from collectors systems (AASHTO 2005).

Once the freeway design standards guide the geometric conception of the road network which directly affects the traffic flow operation and, subsequently, the efficiency and 
accessibility issues, a comparative analysis of policies between two developed countries is useful to infer different approaches regarding the influence of these in country's development.

Both American and the Portuguese standards arise from common design theories and are well organized with respect to several elements of design approaches. Therefore, to describe the differences between a freeway project in Portugal and in USA, the comparative standard analysis is introduced by the design controls and criteria that include speed and traffic and, subsequently, the elements of design that include three main sections: sight distance, horizontal alignment, and vertical alignment. Afterward, the cross section elements are presented.

\section{Design controls and criteria}

\subsection{Speed}

The parameter required in any highway project is the design speed, also called the design control. Table 1

\begin{tabular}{|c|c|c|c|c|}
\hline & & & \\
\hline & & \multicolumn{2}{|c|}{ Portugal } & \multirow{2}{*}{$\frac{\text { USA }}{\text { Design Speed }}$} \\
\hline & & Design Speed & Operating Speed & \\
\hline \multicolumn{2}{|c|}{ Sight Distance } & & $x$ & $x$ \\
\hline $\begin{array}{l}\text { Horizontal } \\
\text { Alignment }\end{array}$ & Minimum Radius & $x$ & & $x$ \\
\hline \multirow{2}{*}{$\begin{array}{c}\text { Vertical } \\
\text { Alignment }\end{array}$} & Critical Distance & $x$ & & $x$ \\
\hline & Minimum radius & & $x$ & $x$ \\
\hline \multicolumn{2}{|c|}{ Cross Section } & $x$ & & $x$ \\
\hline
\end{tabular}

Table 1: Speed criteria in each element of design (JAE 1994, AASHTO 2011)

The minimum design speed of a freeway is $80 \mathrm{~km} / \mathrm{h}(50 \mathrm{mph})$ in both countries, whereas the maximum value of design speed is $140 \mathrm{~km} / \mathrm{h}(85 \mathrm{mph})$ in Portugal and $130 \mathrm{~km} / \mathrm{h}(80 \mathrm{mph})$ in USA (JAE 1994, AASHTO 2011).

Besides the design speed, Portugal considers another speed to have in consideration in some design stages: the operating speed which is the $85^{\text {th }}$ percentile distribution observed speeds in free-flow conditions. Table 2 exhibits the quantitative relation of speeds.

\begin{tabular}{cccccccc}
\hline Design Speed & 80 & 90 & 100 & 110 & 120 & 130 & 140 \\
\cline { 1 - 8 } & 100 & 110 & 120 & 125 & 130 & 135 & 140 \\
\hline Operating Speed & 100 2: Relationship between design and operation speed
\end{tabular}
considered by Portuguese Policy [km/h] (JAE 1994)

Once the operating speed is considerably higher than the design speed (see Error! Reference source not found.), the first impression from the analysis of Table 1 relates that the sight distance and the vertical radii from Portuguese standards will surpass the USA normative values.

Table 3 presents a summary of the design speed in each freeway category, where the design speed is the used in project conception and the speed limit is the signalized speed limit visible in freeways.

It is possible to infer that Portugal demands a higher design speed than USA. For the maximum level of freeways, the difference in the speed limit is just $10 \mathrm{~km} / \mathrm{h}$ ( $5 \mathrm{mph}$ ) but 
considering the design speed, the difference can be up to $20 \mathrm{~km} / \mathrm{h}$ (10 mph). At first impression, the safety issue is more easily guaranteed by Portuguese standards, once the design speed attains a larger gap in comparison with American speed. On the other hand, the analysis of the urban freeways, it seems that both policies are aligned with the same design speed and speed limit: $80 \mathrm{~km} / \mathrm{h}$ (50 mph).

\section{Design Speed $\quad$ Speed Limit}

\begin{tabular}{|c|c|c|c|}
\hline \multirow{5}{*}{ Portugal } & \multirow{2}{*}{ Interurban freeway } & 140 & 120 \\
\hline & & 120 & 120 \\
\hline & Interurban freeway in difficult topography & 80 & $\begin{array}{c}100 \\
(80, \text { if radius }<450 \mathrm{~m})\end{array}$ \\
\hline & Suburban freeway & 100 & 100 \\
\hline & Urban freeway & 80 & 80 \\
\hline \multirow{4}{*}{ USA } & Interstates & 120 & 110 \\
\hline & Freeways \& Expressways & 110 & 100 \\
\hline & \multirow{2}{*}{ 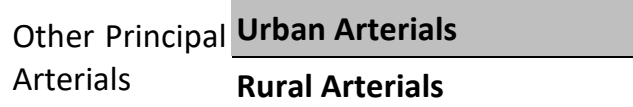 } & 80 & 80 \\
\hline & & 110 & 110 \\
\hline
\end{tabular}

Table 3: Design speed of each freeway category in Portugal and United States of America [km/h] (InIR 2008, AASHTO 2005)

\subsection{Traffic}

Traffic is an important aspect for the highway project in the geometric characteristics of the cross section elements. The level of service and the design traffic flow are the two most fundamental parameters defined a priori the geometry of the design project.

The level of service specified in HCM (2010) must be guaranteed in and depends on the freeway category. Table 4 is adapted from InIR (2008) and FHT (2013).

\begin{tabular}{|c|c|c|c|c|c|c|c|c|c|}
\hline & & & \multirow[b]{2}{*}{ Design Speed [km/h] } & \multicolumn{6}{|c|}{ Minimum Level of Service } \\
\hline & & & & A & B & $\mathbf{C}$ & D & $\mathbf{E}$ & $\mathbf{F}$ \\
\hline \multirow{5}{*}{ Portugal } & \multirow{2}{*}{\multicolumn{2}{|c|}{ Interurban freeway }} & $\approx 140$ & & $x$ & & & & \\
\hline & & & $\approx 120$ & & & $x$ & & & \\
\hline & \multicolumn{2}{|c|}{$\begin{array}{l}\text { Interurban freeway in difficult } \\
\text { topography }\end{array}$} & $\approx 80$ & & & $x$ & $x$ & & \\
\hline & \multicolumn{2}{|c|}{ Suburban freeway } & $\approx 100$ & & & $x$ & & & \\
\hline & \multicolumn{2}{|l|}{ Urban freeway } & $\approx 80$ & & & $x$ & $x$ & & \\
\hline \multirow{4}{*}{ USA } & \multicolumn{2}{|l|}{ Interstates } & $\approx 120$ & & $x$ & & & & \\
\hline & \multicolumn{2}{|c|}{ Freeways \& Expressways } & $\approx 110$ & & & $x$ & & & \\
\hline & \multirow{2}{*}{$\begin{array}{l}\text { Other Principal } \\
\text { Arterials }\end{array}$} & Urban Arterials & $\approx 80$ & & & & $\mathrm{x}$ & & \\
\hline & & Rural Arterials & $\approx 110$ & & $x$ & $x$ & & & \\
\hline
\end{tabular}

Table 4: Normative considerations of level of service regarding the freeway classification in Portugal and United States of America

With respect to Table 4, it seems that both policies require similar levels of services for the respective freeway classification. However, in the highest freeway category, USA Policy demand a B level of service and Portuguese Policy demands a $\mathrm{C}$ level of service for the same 
design speed $(120 \mathrm{~km} / \mathrm{h})$. In the urban freeways, it happens the opposite scenario, Portuguese Policy demand a C or D level of service and USA Policy demand a D level.

\section{Elements of Design}

\subsection{Sight Distance}

The sight distance is the driver's ability to see ahead and has the utmost importance in safety.

The stopping sight distance is one type of sight distances. In fact, it is the minimum visibility distance, leading to the minimum distance from an object that the driver needs to be able to see it so that he can stop before colliding. The stopping distance can be calculated from the instant when a driver sees an obstacle to the instant that the vehicle stops. It depends upon the speed, brake reaction time and coefficients of longitudinal grip.

The decision sight distance surpass the stopping sight distance and is important at interchange locations, at changes in cross section such as toll plazas and lane drops, and for approximations to service areas where drivers need to make complex or prompt decisions. It depends on the speed and the pre-manoeuvre and manoeuvre time, which in Portugal is fixed to 12 seconds, and in USA there are two categories: 12.5 and 14.25 seconds of decision (see Table 5).

\begin{tabular}{|c|c|c|c|c|c|}
\hline \multirow{3}{*}{$\begin{array}{l}\text { Design } \\
\text { Speed } \\
{[\mathrm{km} / \mathrm{h}]}\end{array}$} & \multicolumn{2}{|c|}{ Portugal } & \multicolumn{3}{|c|}{ USA } \\
\hline & \multirow{2}{*}{$\begin{array}{l}\text { Stopping Sight } \\
\text { Distance }\end{array}$} & \multirow{2}{*}{$\begin{array}{c}\text { Decision Sight } \\
\text { Distance }(12.00 \mathrm{~s})\end{array}$} & \multirow{2}{*}{$\begin{array}{l}\text { Stopping Sight } \\
\text { Distance }\end{array}$} & \multicolumn{2}{|c|}{ Decision Sight Distance } \\
\hline & & & & (12.00 s) & (14.25 s) \\
\hline 80 & 180 & 330 & 130 & 270 & 315 \\
\hline 90 & 220 & 370 & 160 & 315 & 360 \\
\hline 100 & 250 & 400 & 185 & 355 & 400 \\
\hline 110 & 280 & 410 & 220 & 380 & 430 \\
\hline 120 & 320 & 430 & 250 & 415 & 470 \\
\hline 130 & 330 & 450 & 285 & 450 & 510 \\
\hline 140 & 390 & 470 & & & \\
\hline
\end{tabular}

Table 5: Minimum admissible sight distances [m] (InIR 2010, AASHTO 2011)

Table 5 is a summary of the minimum sight distances considered in both countries, namely the stopping and the decision sight distance. The analysis indicates that American policy is less strict than Portuguese. Taking into account the speeds considered in this element of design (Table 1), the Portuguese standards use an operating speed that is higher than the design speed (Table 2) which explains the difference between the two regulations. This consideration may infer that the larger is the sight distances the higher is the safety in freeway sections.

\subsection{Horizontal Alignment}

The geometric parameters of the horizontal alignment include the straight sections, circular curves and transition curves.

Regarding the straight sections, Portuguese standards restrict the extension of straight sections, with constant slope, to a maximum circulation time of 72 seconds (JAE 1994), in order to avoid monotony of the design which could cause tiredness or numbness (see equation 1). They also demand a minimum distance between successive curves of 5 seconds in the design speed settled initially (JAE 1994). 
Regarding circular curves, the radius is the key constraint and is subject to the side friction factor, design speed and superelevation: $7 \%$ and $8 \%$ for Portugal and USA, respectively (InIR 2010, AASHTO 2011). Portugal uses a comfort radius to restrain the centrifugal acceleration in the curve to $1.08 \mathrm{~m} / \mathrm{s}^{2}$. The contrast of the radius between these two countries is also evident in Table 6 . With respect to the safety radius, it is evident that there is a similarity however Portuguese normative values are always higher than American. With respect to comfort radius, which in practice is the most used, the dissimilarity between the two polices is huge.

\begin{tabular}{|c|c|c|c|}
\hline \multirow{2}{*}{$\begin{array}{c}\text { Design Speed } \\
{[\mathrm{km} / \mathrm{h}]}\end{array}$} & \multicolumn{2}{|c|}{ Portugal } & \multirow{2}{*}{$\frac{\text { USA }}{\text { Safety Radius }}$} \\
\hline & Safety Radius & Comfort Radius & \\
\hline 80 & 240 & 450 & 230 \\
\hline 90 & 320 & 550 & 305 \\
\hline 100 & 420 & 700 & 395 \\
\hline 110 & 560 & 850 & 500 \\
\hline 120 & 700 & 1000 & 665 \\
\hline 130 & 900 & 1200 & 830 \\
\hline 140 & 1200 & 1400 & \\
\hline
\end{tabular}

Table 6: Minimum admissible values of radius [m] (InIR 2010, AASHTO 2011)

Table 7 presents the minimum radius in each freeway category, which is the major geometric parameter in the highway project. Once urban freeways are associated with lower speeds, they are related with lower radii; the same reasoning can be done for interurban freeways with higher radii.

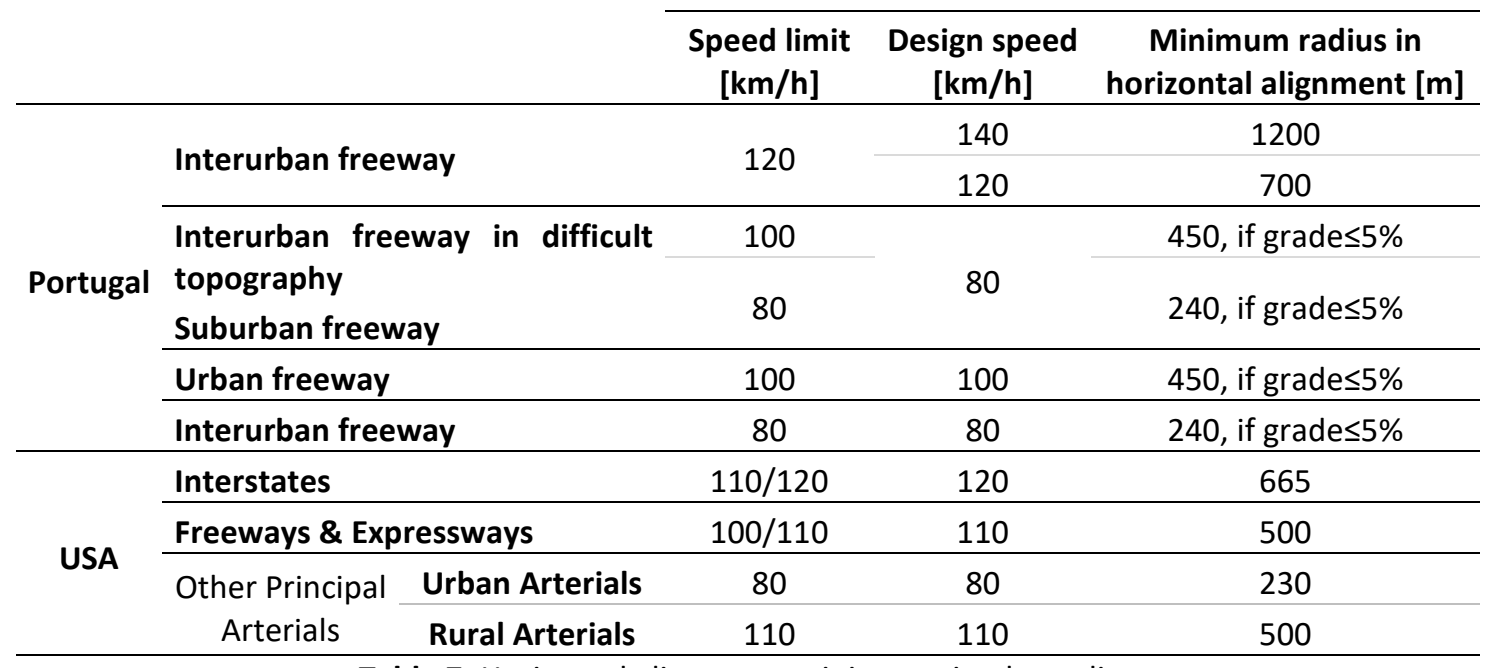

Table 7: Horizontal alignment: minimum circular radius regarding each freeway category (InIR 2010, AASHTO 2011)

Regarding the transition curves analysis, a spiral curve is normally used in both countries, but there are still numeric differences with respect to the use of the spiral transition curve (see Table 8).

\begin{tabular}{cccccccc}
\hline Design Speed $[\mathrm{km} / \mathrm{h}]$ & 80 & 90 & 100 & 110 & 120 & 130 & 140 \\
\hline Portugal & \multicolumn{7}{c}{$\geq 2500$} \\
\hline USA & 379 & 480 & 592 & 716 & 852 & 1000 & - \\
\hline
\end{tabular}

Table 8: Maximum radius for use of a spiral transition curve [m] (InIR 2010, AASHTO 2011) 
This numeric difference commits safety and is tremendously significant once the transition curves gradually increments the lateral acceleration until it reaches the circular curve. Otherwise, the transition between the straight section ends, with null lateral acceleration, and the circular curve, with constant lateral acceleration can cause numerous accidents. In freeways, the circulation speeds are high and this aspect has major importance.

The parameter $(s)$ that confine the spiral curves are: the minimum length or the factor $A$. In Portugal it is the factor $A$, while in USA is the minimum length. The factor $A$ is a constant parameter and depends on the length (I) and the radius ( $r$ ) of the curve in the locus, as presented in equation 2 .

$$
A^{2}=1 * r
$$

Table 9 presents the spiral curve design criteria relative to the factor $A[m]$, where the $V$ is the speed considered $[\mathrm{km} / \mathrm{h}] ; \mathrm{R}$ is the minimum radius of the curve $[\mathrm{m}] ; \mathrm{S}_{a n}$ is the rate of change in lateral acceleration $\left[\mathrm{m} / \mathrm{s}^{3}\right] ; \mathrm{S}_{e}$ is the superelevation [\%]; $\mathrm{i}$ is the cross slope [\%]; $\Delta \mathrm{i}$ $\max$ and $\Delta \mathrm{i}$ min are the maximum and minimum slope, respectively, in superelevation linear attainment [\%]; and, at last, $p_{\max }$ and $p_{\text {min }}$ are the maximum and minimum vertical distance, respectively, between straight section and circular curve [m].

The first criterion was suggested by W. H. Shortt in 1909 and is related to safety and comfort. The second criterion is related to the superelevation attainment, of which the lower bound pertains to geometry and the higher bound to hydroplaning. The third criterion involves at least two seconds of circulation within the transition curve. The fourth criterion concerns the optical comfort. The analysis indicates that both first and third criterion are common, whereas the second is distinct and the fourth criterion is only taken into consideration by Portuguese policy.

\begin{tabular}{|c|c|c|}
\hline Design Criteria & Portugal & USA \\
\hline $1^{\text {st }}-$ Comfort and Safety & & $463 \sqrt{\frac{V^{3}}{S_{a n}}}$ \\
\hline \multirow{2}{*}{$2^{\text {nd }}-$ Superelevation } & $A \geq \sqrt{\frac{R \cdot a(S e-i)}{2 \cdot \Delta i_{\text {máx }}}}$ & $A \geq 2,2134 \cdot p_{\min } \frac{1}{4} \cdot R^{\frac{3}{4}}$ \\
\hline & $A \leq \sqrt{\frac{R \cdot a(S e-i)}{2 \cdot \Delta i_{\min }}}$ & $A \leq 2,2134 \cdot p_{\text {máx }} \frac{1}{4} \cdot R^{\frac{3}{4}}$ \\
\hline $3^{\text {rd }}-$ Aesthetics & & $\sqrt{\frac{V . R}{1,8}}$ \\
\hline $4^{\text {th }}-$ Optical comfort & $A \geq \frac{1}{3} R$ & None \\
\hline
\end{tabular}

Table 9: Spiral curve design criteria in Portugal and United States of America (InIR 2010, AASHTO 2011)

Table 10 presents the minimum admissible values for the parameter A (used in Portugal's design) and the respective minimum length of the spiral (used in USA's design). This calculus takes into consideration the design speed and the minimum radius in circular curve. It is important to note that the radius considered in Portugal is the comfort radius while in the USA is the safety radius (Table 6). 
The main conclusions from Table 10 regard the fact that Portugal requires more length of the transition curve than USA, which is foremost the best for safety, once the transition of the lateral curve occurs more smoothly.

\begin{tabular}{ccccccccc}
\hline & Design Speed $[\mathrm{km} / \mathrm{h}]$ & $\mathbf{8 0}$ & $\mathbf{9 0}$ & $\mathbf{1 0 0}$ & $\mathbf{1 1 0}$ & $\mathbf{1 2 0}$ & $\mathbf{1 3 0}$ & $\mathbf{1 4 0}$ \\
\hline \multirow{2}{*}{ Parameter } & Portugal & 150 & 183 & 233 & 283 & 333 & 400 & 466 \\
\cline { 2 - 8 } & USA & 101 & 123 & 146 & 175 & 211 & 244 & - \\
\hline \multirow{2}{*}{$\begin{array}{c}\text { Minimum } \\
\text { Length }\end{array}$} & Portugal & 50 & 61 & 78 & 94 & 111 & 133 & 156 \\
\cline { 2 - 8 } & USA & 44 & 50 & 56 & 61 & 67 & 72 & - \\
\hline
\end{tabular}

Table 10: Minimum values of factor $A[\mathrm{~m}]$ and length $[\mathrm{m}]$

for each design speed [m] (InIR 2010, AASHTO 2011)

\subsection{Vertical Alignment}

The vertical alignment is constituted by grades, crest and sag curves.

The minimum grade limit is $0.5 \%$ for both countries, whereas the USA policy indicates that it can be considered $0,3 \%$ if the pavement has extremely precision and there is guarantee that it has greater resistance. The maximum grade depends upon terrain and design speed. For a consistent topography, the Portuguese standards limit it to $6 \%(80 \mathrm{~km} / \mathrm{h})$ and $3 \%(140$ $\mathrm{km} / \mathrm{h})$. The American policy limit it to $4 \%(80 \mathrm{~km} / \mathrm{h})$ and $3 \%(130 \mathrm{~km} / \mathrm{h})(\mathrm{InIR} 2010$, AASHTO 2011).

With respect to the critical distance that determines the truck lanes, from Table 11, Portugal is more conservative than the United States of America. This means that Portugal is easily conditioned to design additional lanes for trucks.

\begin{tabular}{|c|c|c|c|c|c|c|c|}
\hline & \multirow{2}{*}{$\begin{array}{l}\text { Initial Speed } \\
{[\mathrm{km} / \mathrm{h}]}\end{array}$} & \multirow{2}{*}{$\begin{array}{c}\text { Reduction } \\
{[\mathrm{km} / \mathrm{h}]}\end{array}$} & \multicolumn{5}{|c|}{ Grade } \\
\hline & & & $2 \%$ & $3 \%$ & $4 \%$ & $5 \%$ & $6 \%$ \\
\hline Portugal & 90 & 15 & $\infty$ & 420 & 300 & 230 & 180 \\
\hline \multirow{4}{*}{ USA } & 90 & 15 & $\infty$ & $\infty$ & 800 & 500 & - \\
\hline & 110 & 15 & 1000 & 525 & 375 & 275 & - \\
\hline & 90 & 25 & $\infty$ & $\infty$ & $\infty$ & 1250 & - \\
\hline & 110 & 25 & $\infty$ & 900 & 600 & 460 & - \\
\hline
\end{tabular}

Table 11: Minimum admissible values of critical distance for vertical alignment [m] (InIR 2010, AASHTO 2011)

The minimum radii for crest and sag curves are shown in Table 12. As for the horizontal alignment, the Portuguese normative endorse the use of comfort radius. The analysis exposes the same policy pattern, the Portuguese policy demand higher geometric values in crest and sag curves in comparison to the American normative values. Moreover, in the case of crest curves this difference is much greater. This situation is due to the use of operating speed in Portugal rather than the use of design speed (slightly lower) in USA. 


\begin{tabular}{|c|c|c|c|c|c|}
\hline \multirow{3}{*}{$\begin{array}{l}\text { Design } \\
\text { Speed } \\
{[\mathrm{km} / \mathrm{h}]}\end{array}$} & \multicolumn{3}{|c|}{ Sag Curves } & \multicolumn{2}{|c|}{ Crest Curves } \\
\hline & \multicolumn{2}{|c|}{ Portugal } & \multirow{2}{*}{$\frac{\text { USA }}{\text { Safety Radius }}$} & \multirow{2}{*}{$\begin{array}{c}\text { Portugal } \\
\text { Safety Radius }\end{array}$} & \multirow{2}{*}{$\frac{\text { USA }}{\text { Safety Radius }}$} \\
\hline & Safety Radius & Comfort Radius & & & \\
\hline 80 & 5000 & 6000 & 2600 & 3500 & 2940 \\
\hline 90 & 7500 & 8500 & 3900 & 4500 & 3760 \\
\hline 100 & 9000 & 12500 & 5200 & 5500 & 4460 \\
\hline 110 & 12000 & 13000 & 7400 & 6000 & 5440 \\
\hline 120 & 14000 & 16000 & 9500 & 7000 & 6280 \\
\hline 130 & n.a. & n.a. & 12400 & 8000 & 7270 \\
\hline 140 & 20000 & 20000 & & 8000 & \\
\hline
\end{tabular}

Table 12: Minimum admissible values of radius for vertical alignment [m] (InIR 2010, AASHTO 2011)

Table 13 presents the normative considerations regarding the vertical alignment design and each freeway category from both countries. For high speed freeways (interurban zones), the radii are obviously superior than the low speed freeways (urban or rural zones). Furthermore, the USA radii are far inferior than the Portuguese radii. The differences between the two policies is so obvious that when analysing the sag and crest radii, from bottom to top, the radii are gradually increasing.

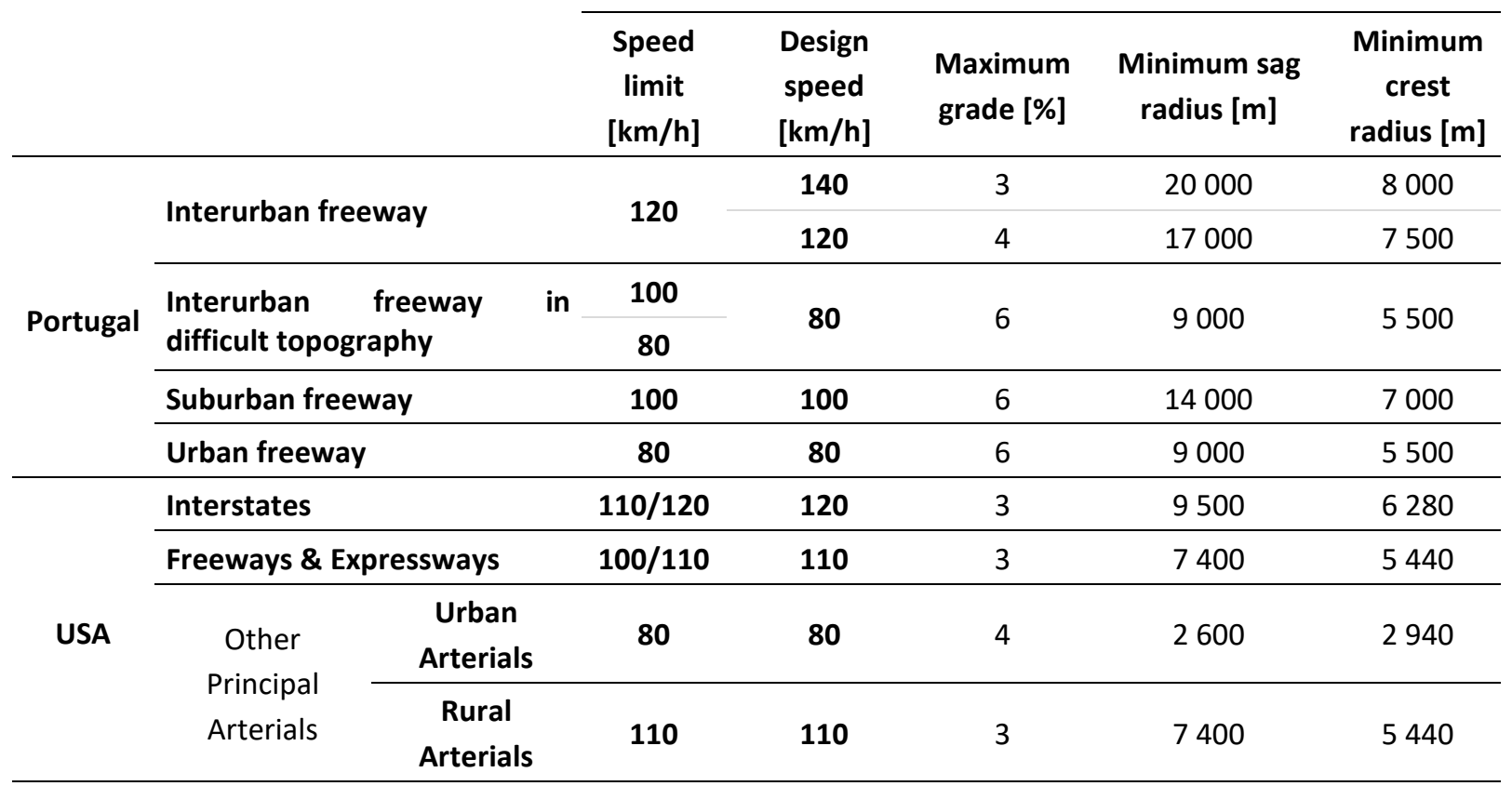

Table 13: Vertical alignment design: sag and crest curves radii contemplating the freeway type (InIR 2010, AASHTO 2011)

\section{Cross section elements}

With respect to the cross section elements the geometric parameters include lanes, cross slope, lanes width, shoulders, medians, superelevation, sideslopes and superelevation attainment.

The number of lanes is mainly influenced by the level of service required for each specific case. However, at least two lanes for each direction is required in both countries.

In Portugal, the cross slope is recommended to be $2.5 \%$ for flexible pavements and $2.0 \%$ for rigid pavement (InIR 2008). However, AASHTO (2011) Policy recommends the use of $2.0 \%$ but admits a minimum value of $1.5 \%$. 
Regarding the width of the lanes, in Portugal the recommended geometric value is 3.50 meters for all types of freeways, except for interurban freeways (highest level of Portuguese freeways - see section 1) where a width of 3.75 meters is required. AASHTO (2005) Policy indicates 3.60 meters as a minimum reference width for American freeways.

With respect to external shoulders, Portuguese Policy (InIR 2008) recommends 2.50 meters; however it admits a minimum value of 2.00 meters for urban freeways (lowest level of Portuguese freeways) whereas it advises a 3.00 meters for interurban freeways (highest level of Portuguese freeways). Regarding the internal shoulder, in general they recommend 1.00 meters but for interurban freeways they mention 1.50 meters. On the other hand, AASHTO (2005) recommends a minimum value of 3.00 meters for external shoulders and 1.20 meters for internal shoulders.

Portuguese Standards indicate a maximum value of superelevation of $7 \%$ whereas in the United States of America it is usually stated a value of $8 \%$ (AASHTO 2011). However, AASHTO (2011) admit $10 \%$ in regions with severe winter climates, limiting a maximum value of $12 \%$.

Regarding the medians width, Table 14 presents the Policy recommendations in both countries. Despite the fact that Portugal admits widths of medians with barriers about 1.50 meters, the majority of freeways are designed for high speeds where the minimum width of 3.00 meters is used like in the United States of America. In medians without barriers, Portuguese Policy consider high widths, recommended to be above 20.00 meters.

\begin{tabular}{ccc}
\cline { 2 - 3 } & Portugal & USA \\
\hline With Barriers: Median $<8 \mathrm{~m}$ & 1.50 (Minimum) & 3.00 \\
Recommendations: & $\geq 4.00$ interurban freeways with design speed $140 \mathrm{~km} / \mathrm{h}$ & \\
& $\geq 3.00$ interurban freeways with design speed $130 \mathrm{~km} / \mathrm{h}$ & \\
& $\geq 0.60$ urban freeways & 11.00 (Minimum) \\
\hline Without Barriers: Median $\geq 8 \mathrm{~m}$ & 11.50 (Minimum for safety) & 20.00 (Minimum) \\
\hline
\end{tabular}

Table 14: Policy recommendations for medians

in cross sections elements [m] (InIR 2010, AASHTO 2011)

The sideslopes are imperative for an efficient drainage system. In freeways, they usually have an inverted triangular form, with minimum width of 1.20 meters and depth about 0.20 meters under the shoulder height. Portuguese standards recommend backslopes of $1 \mathrm{~V}: 4 \mathrm{H}$ (maximum) and foreslopes of $1 \mathrm{~V}: 2 \mathrm{H}$ (In/R 2010. In USA, the channel sideslopes are recommended about $1 \mathrm{~V}: 6 \mathrm{H}$ but they admit a maximum of $1 \mathrm{~V}: 4 \mathrm{H}$ for backslopes (AASHTO 2011).

A summary of cross section elements is presented in Table 15.

\begin{tabular}{cccccc} 
& $\begin{array}{c}\text { Cross } \\
\text { Slope }\end{array}$ & $\begin{array}{c}\text { Max. } \\
\text { Superelevation }\end{array}$ & $\begin{array}{c}\text { Lanes } \\
{[\mathrm{m}]}\end{array}$ & $\begin{array}{c}\text { Shoulder } \\
\text { Ext / Int [m] }\end{array}$ & With Barriers / Without Barriers [m] \\
\hline Portugal & $2.5 \%$ & $7 \%$ & 3.50 & $3.00 / 1.50$ & $1.50 / 11.50$ \\
\hline USA & $2.0 \%$ & $8 \%$ & 3.60 & $3.00 / 1.20$ & $3.00 / 11.00$ \\
\hline
\end{tabular}

Table 15: Minimum admissible values of parameters for cross sections (InIR 2010, AASHTO 2011)

\subsection{Superelevation considerations}

The superelevation tables improve the geometric design and the superelevation designed depends on the design speed and radius. Therefore, Portugal and USA have both distinct 
ways to infer in the design value of this parameter. Table 16 in referred to Portugal and Table 17 is referred to United States of America, both tables are adapted.

\begin{tabular}{cccccccccccc}
\hline Radius [m] & $<900$ & 1100 & 1300 & 1500 & 1750 & 2000 & 2250 & 2600 & 3000 & $3500<R<5000$ & $>5000$ \\
\hline $\begin{array}{c}\text { Superelevation } \\
\text { [\%] }\end{array}$ & 7 & 6,5 & 6 & 5,5 & 5 & 4,5 & 4 & 3,5 & 3 & 2,5 & 0 \\
\hline
\end{tabular}

Table 16: Minimum Radii [m] for Design Superelevation Rates, adapted from InIR (2010)

\begin{tabular}{cccccccc}
\hline \multicolumn{2}{c}{ Design speed [km/h] } & $\mathbf{8 0}$ & $\mathbf{9 0}$ & $\mathbf{1 0 0}$ & $\mathbf{1 1 0}$ & $\mathbf{1 2 0}$ & $\mathbf{1 3 0}$ \\
\hline & $\mathbf{2 , 0}$ & 1790 & 2190 & 2680 & 3090 & 3640 & 4000 \\
\cline { 2 - 7 } & $\mathbf{2 , 2}$ & 1620 & 1980 & 2420 & 2790 & 3290 & 3620 \\
\cline { 2 - 7 } & $\mathbf{3 , 0}$ & 1150 & 1410 & 1730 & 2000 & 2370 & 2630 \\
\cline { 2 - 7 } $\begin{array}{c}\text { Superelevation } \\
{[\%]}\end{array}$ & $\mathbf{4 , 0}$ & 813 & 1010 & 1240 & 1450 & 1740 & 1950 \\
\cline { 2 - 7 } & $\mathbf{5 , 0}$ & 611 & 762 & 947 & 1120 & 1360 & 1540 \\
\cline { 2 - 7 } & $\mathbf{6 , 0}$ & 469 & 595 & 746 & 894 & 1100 & 1260 \\
\cline { 2 - 7 } & $\mathbf{7 , 0}$ & 358 & 464 & 591 & 724 & 914 & 1070 \\
\hline & $\mathbf{8 , 0}$ & 229 & 304 & 394 & 501 & 667 & 832 \\
\hline
\end{tabular}

Table 17: Minimum Radii [m] for Design Superelevation Rates, Design Speeds, and superelevation $\max =8 \%$, adapted from AASHTO (2011)

In Portuguese freeway design, the superelevation value is subject to the design speed which automatically influences the radii which in Portugal, for the same speed it exists two radii (safety and comfort). If the design radius is the safety radius, the superelevation value is the maximum, 7\%. If it is the comfort radius, the superelevation value is picked directly from Table 16. When, the design radius is between the safety and comfort radius, then an interpolation must be done.

The USA design speed and the design superelevation imply the verification if the design radius is equal or superior to the one exhibited in Table 17.

The comparison of these two policies can be done through the uncompensated radial acceleration entailing two examples of freeway design. The first example considers a design speed of $100 \mathrm{~km} / \mathrm{h}$ (60 mph) and a radius of 1100 meters. The second example considers a design speed of $80 \mathrm{~km} / \mathrm{h}(50 \mathrm{mph})$ and a radius of 300 meters. Table 18 shows the correspondent results of each examples in accordance with both policies.

\begin{tabular}{|c|c|c|c|c|}
\hline & \multicolumn{2}{|c|}{$\begin{array}{c}1^{\text {st }} \text { Example } \\
\text { Design Speed }=100 \mathrm{~km} / \mathrm{h} \\
\text { Radius }=\mathbf{1 1 0 0} \mathrm{m}\end{array}$} & \multicolumn{2}{|c|}{$\begin{array}{c}2^{\text {nd }} \text { Example } \\
\text { Design Speed }=80 \mathrm{~km} / \mathrm{h} \\
\text { Radius }=300 \mathrm{~m}\end{array}$} \\
\hline & Superelevation & $\begin{array}{l}\text { Uncompensated radial } \\
\text { acceleration }\left[\mathrm{m} / \mathrm{s}^{2}\right]\end{array}$ & Superelevation & $\begin{array}{c}\text { Uncompensated radial } \\
\text { acceleration }\left[\mathrm{m} / \mathrm{s}^{2}\right]\end{array}$ \\
\hline Portugal & $6.5 \%$ & 0.064 & $7.0 \%$ & 0.959 \\
\hline USA & $4.4 \%$ & 0.270 & $7.6 \%$ & 0.901 \\
\hline
\end{tabular}

For high-speed freeways with larger radius, the Portuguese normative is more conservative and safer with an uncompensated radial acceleration almost null. However, for low-speed freeways and conservative radius, it is the most uncomfortable despite the similarity with American normative.

Table 19 presents the radii when there is no need of superelevation. In Most of the cases, the Portuguese policy is conservative because requires a higher radius than USA policy, for the same design speed. 


\begin{tabular}{ccccccr}
\hline Design Speed $[\mathrm{km} / \mathrm{h}]$ & 80 & 90 & 100 & 110 & 120 & 130 \\
\hline Portugal & & 2500 & & 5000 & \\
\hline USA & 2440 & 2970 & 3630 & 4180 & 4900 & 5360 \\
\hline Table 19. Radii $[\mathrm{m}]$
\end{tabular}

In freeways, the risk of aquaplaning is much greater for several reasons: the fact the waterproofing area is vaster (high number of lanes), the use of small cross slope and grade, the high speed practiced, longer lengths of superelevation attainment, loss of efficiency in the draining pavements (clogging of pores), among others. Thus, non-linear, i.e., the parabolic models are the most suitable for the superelevation attainment of the outer band. However, the parabolic models are not as used as demanded, once the linear models are more innate and easy to implement in practice.

Regarding the methods of attaining superelevation, in USA AASHTO recommends the simplified parabolic method where the superelevation and side friction are in a curvilinear relation with the inverse of the radius of the curve. Equation 3 presents the superelevation function where: Se is the superelevation design value [\%], $i$ is the cross slope [\%]; $L^{\prime}=L d+L$, and: $L d$ is the extension where the attainment occurs in straight section $[\mathrm{m}], \mathrm{L}$ is the extension where the attainment occurs in transition curve [m].

$$
\operatorname{Se}(x)=\left[3-\frac{2 x}{L^{\prime}}\right]\left(\frac{x}{L^{\prime}}\right)^{2} *(S e+i)-i
$$

Figure 1 illustrates the method of attaining superelevation, presented in equation (3).

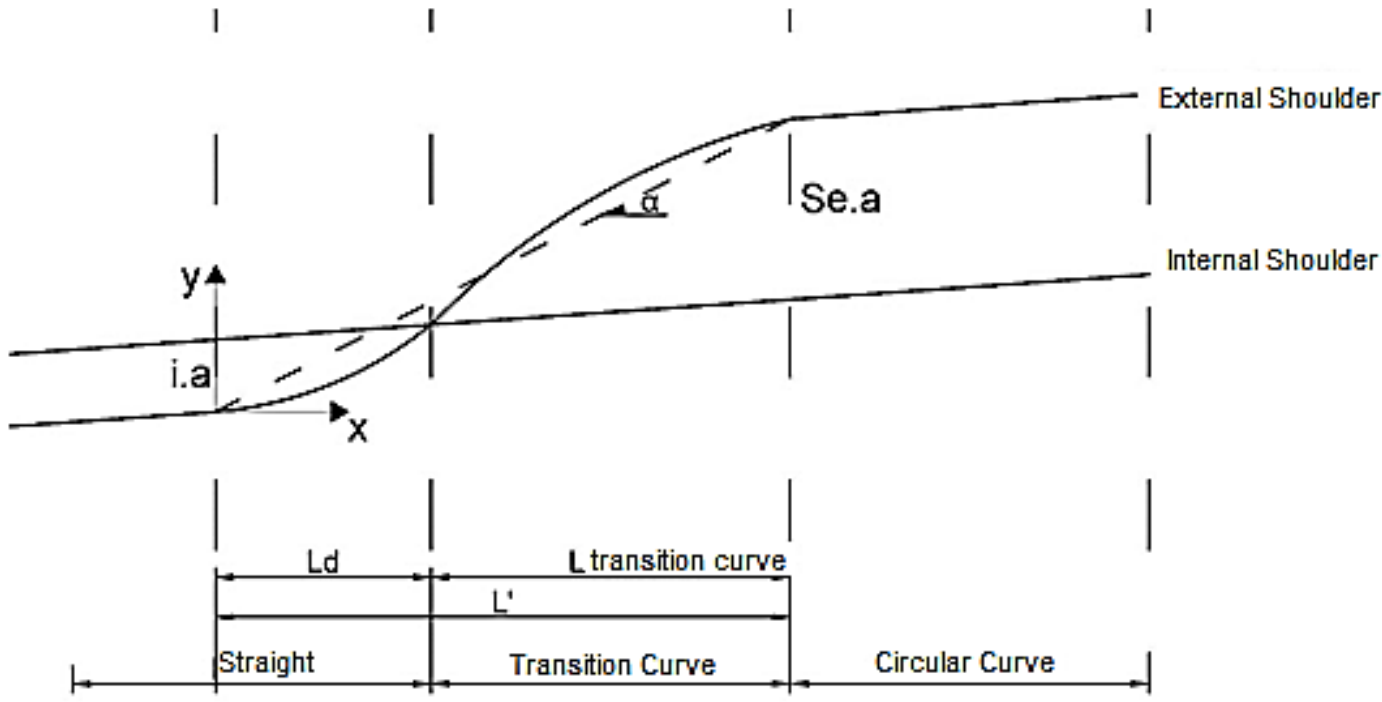

Figure 1: Simplified parabolic method scheme

Regarding the Portuguese Policy, there is no such recommendation of a parabolic method to attain superelevation. However, it is commonly suggested to use this method in any freeway engineering projects (Pereira 2014). There are four restrains in this model: in the initial point of the curve $(R=\infty)$, the superelevation value is null; in the final point of the transition curve, the superelevation is the designed; in the first section of the transition curve, the derived of the curve must be $\delta$, to help drainage; in the last point of the transition curve, the derived of the curve must be null (França n.d.).

Therefore, its mathematical expression is referred in equation 4 , where $\mathrm{Se}^{\max }$ is the superelevation design value [\%]; $L$ is the extension where the attainment occurs in transition 
curve [m]; $a$ is the carriageway width $[\mathrm{m}]$; and $\delta$ is the derived of superelevation attainment in the beginning of transition curve (recommended values between 0.8 and $1.0 \%$ ).

$$
\operatorname{Se}(x)=\left[\frac{L \frac{\delta}{a}-2 S e^{\max }}{L^{3}}\right] x^{3}+\left[\frac{-2 L \frac{\delta}{a}+3 S e^{\max }}{L^{2}}\right] x^{2}+\frac{\delta}{a} x
$$

The visual scheme of equation (4) is presented in Figure 2.

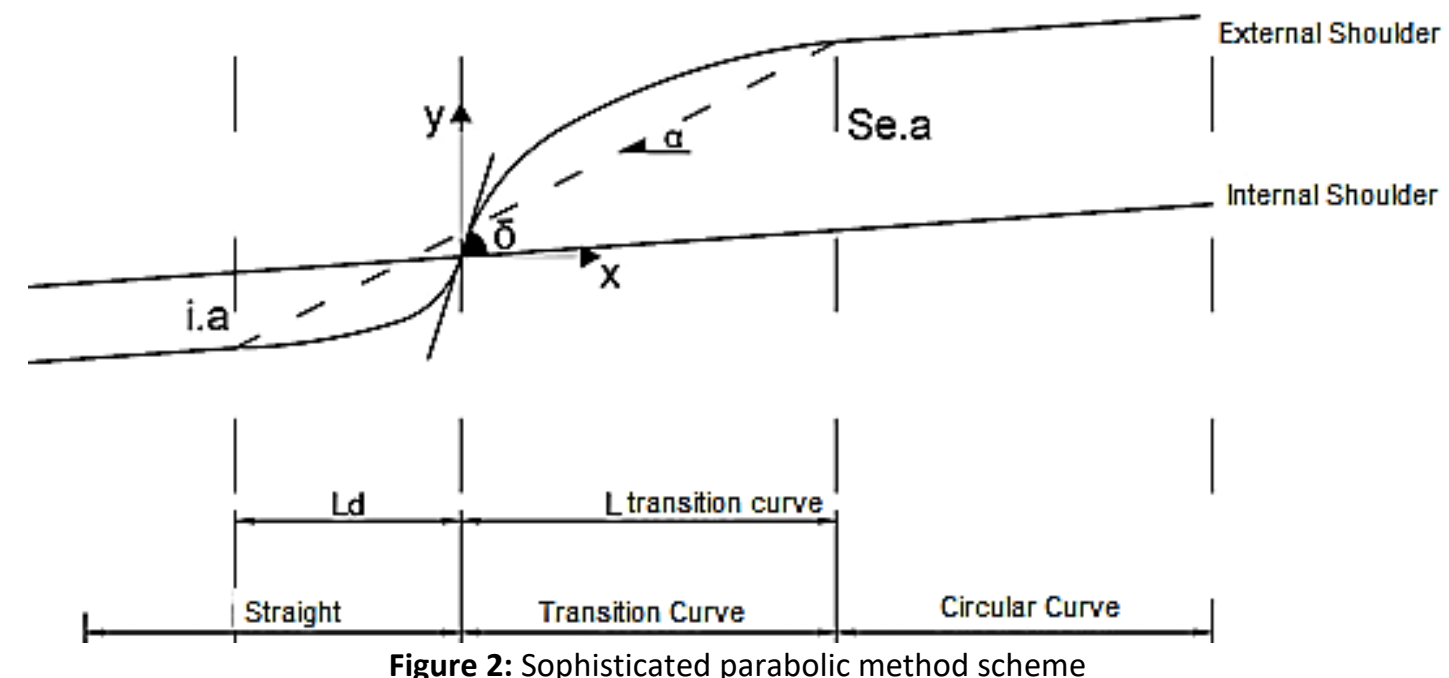

\section{Additional freeway features}

Regarding the height between the freeway pavement and the viaducts, AASHTO (2011) recommends 4.9 meters in rural areas and freeways surrounding significant urban areas. In general, a minimum value of 4.3 meters is admitted.

Regarding pedestrians structures, they shall have a minimum height of 5.1 meters (AASHTO 2005).

In Portugal, this minimum height is not normalized but, in practice, it is often adopted a height between the freeway pavement and structures about 5.0 meters.

In tunnels, USA Policy indicates a minimum height of 4.9 meters, and in exceptional situations 4.3 meters. With respect to the carriageway, a minimum value of 13.1 meters is recommended (3.6 meters each), but never under 9.0 meters (AASHTO 2005). The right shoulder shall be about 3.0 meters and left shoulder about 1.5 meters. AASHTO (2005) also indicates the necessity of 0.50 meters for sidewalk but it is recommended the value of 1.0 meters.

In Portugal, a minimum height in tunnels shall be around 4.50 meters, up to 4.80 meters. The cross slope adopted should be around $2 \%$, double tunnels, with two or three lanes. The carriageway width is recommended to be about 7.30 for two lanes and 11.30 for three lanes. The sidewalks shall have width between 0.60 and 1.00 meters (Macedo 1994).

\section{Conclusions}

The freeway design presented several similarities in theoretical terms and approaches, but, when numerically applied in both policies, the geometric parameters presented different minimum admissible values. This fact is due to the national consideration of the speed in each freeway category. Furthermore, the freeway design considers geometric parameters that are subjected to weather climate conditions such as the superelevation, cross slope and 
coefficients of longitudinal grip. These coefficients are related to the pavement, which can consider higher values in drier climate weathers.

The review revealed Portuguese Policy implies wider and extensive freeways that arise from strong restraints in the minimum values of geometric parameters. This occurrence reflects on higher safety frame. On the opposite, the American Policy is less conservative which reflects on minor freeways. This fact infers that the American freeways induce in less expensive freeways.

The relationship between the policy on freeway design and its impact on accessibility and the country's development is someway inexact and ambiguous. In general, the higher the restrains that care for safety, the expensive the freeways which presumes a certain level of the country's development. However, both Portugal and United States of America are developed countries and the dissimilarity regarding the policy on geometric design is notable.

For future perspectives of research, there is a necessity to reach to an optimal policy that balances both safety and economic issues. This research would lead to a better judgement about the policies' considerations and is extremely useful both for developed and under development countries, once it would manage the importance of having future safe and economic freeways. Furthermore, research regarding the impact of freeway design policy in the country's development and accessibility would be remarkably valuable since its relationship is often misjudged and overrated.

\section{References}

AASHTO. 2005. Policy on Design Standards Interstate System. Washington, DC: American Association of State Highway and Transportation Officials (AASHTO).

AASHTO. 2011. Policy on Geometric Design of Highways and Streets (6th Edition) with 2012 Errata. Vol. 6th ed. Washington, DC: American Association of State Highway and Transportation Officials (AASHTO).

FHT. 2013. Highway Functional Classification: Concepts, Criteria and Procedures. Vol. FWHAPL-13-026. Washington, DC: U.S. Departament of Transportation, Federal Highway Transportation (FHT).

França, Adalberto. n.d., Portugal.

InIR. 2008. Auto-estradas - Características técnicas. In Instituto de Infra-Estruturas Rodoviárias, edited by Eng. João Bernardo Pessoa Begonha. Lisboa, Portugal: Instituto de Infra-Estruturas Rodoviárias IP.

InIR. 2010. Norma de Traçado - Revisão. In Instituto de Infra-Estruturas Rodoviárias, edited by ENGIVIA and LNEC. Lisboa, Portugal: Instituto de Infra-Estruturas Rodoviárias IP.

JAE. 1994. Norma de Traçado. In Junta Autónoma de Estradas, edited by Portugal Almada. Portugal: Junta Autónoma de Estradas.

Macedo, António Lemonde de. 1994. "O traçado de túneis rodoviários." Seminário "Túneis Rodoviários", Lisboa.

Pereira, Lígia. 2014. "Projeto de Autoestradas do México: Comparação com o Caso Português." Master, Department of Civil Engineering, Faculty of Engineering University of Porto.

PRN. 2000. Plano Rodoviário Nacional aprovado pelo Decreto-Lei n. 222/98 de 17 de Julho (D.R. I Série-A n.o 163), rectificado pela Declaração de Rectificação n. 19-D/98 (D.R. I 
Série-A n. 252), pela Lei no. 98/99 de 26 Julho (D.R. I Série-A n.o 172) e pelo DecretoLei n.o 182/2003 de 16 de Agosto (D.R. I Série-A n.o 188).

TRB. 2010. Highway Capacity Manual 2010, Volumes 1 - 4: Transportation Research Board.

\section{Acknowledgement}

First author acknowledges fruitful discussions with Professor Carlos Rodrigues, from the University of Porto, as well Eng. Rui Correia and Eng. Luís Gonçalves, from GEG (Gabinete de Estruturas e Geotecnia), a Portuguese consultancy company. 